\title{
Writing Final Year Project Report in English: Problems, Motivating and Hindering Factors among UTeM Final Year Engineering Students
}

\author{
Noor Baiduri Abd Halim (Corresponding author) \\ Centre for Languages \& Human Development, Universiti Teknikal Malaysia Melaka \\ Hang Tuah Jaya 76100, Durian Tunggal Melaka, Malaysia \\ Tel: 60-6-331-6932Ｅ-mail: baiduri@utem.edu.my \\ Nordayana Izyan Ahmad Ahsan \\ Centre for Languages \& Human Development, Universiti Teknikal Malaysia Melaka \\ Hang Tuah Jaya 76100, Durian Tunggal Melaka, Malaysia \\ Tel: 60-6-331-6932Ｅ-mail: izyan@utem.edu.my \\ Fudhail Abdul Munir \\ Faculty of Mechanical Engineering, Universiti Teknikal Malaysia Melaka \\ Hang Tuah Jaya 76100, Durian Tunggal Melaka, Malaysia \\ Tel: 60-6-234-6916 E-mail: fudhail@utem.edu.my
}

Received: May 14, 2011

Accepted: November 10, $2011 \quad$ Published: January 1, 2012

doi:10.5539/ass.v8n1p27

URL: http://dx.doi.org/10.5539/ass.v8n1p27

The research is financed by Universiti Teknikal Malaysia Melaka. Grant No. PJP/2010/PBPI(16G)/S00814

\begin{abstract}
In this study, the scope is confined to final year engineering students where the aim of the paper is primarily to look at the motivating and hindering factors for these students to choose the English language when preparing for their final year engineering project reports. These students are from four engineering faculties in Universiti Teknikal Malaysia Melaka (UTeM). A quantitative approach was employed in this study. A total of $201 \mathrm{UTeM}$ final year engineering students were involved in the survey done for this study. The study found that the tasks of understanding, selecting and integrating resources to their projects, not to forget the problem of composing the paper which is always influenced by their first language, are always the hindering factor for the students. Many students did not begin to learn how to approach this task until they were in the process of writing the report. Meanwhile, students are mostly motivated to write report in English due to the dominantly available resources relevant to their project topic written in English.
\end{abstract}

Keywords: Motivating and hindering factors, Engineering project report, Quantitative methods

\section{Introduction}

Writing a final year project report is a most formidable task for many students especially engineering students. This is not only because of the daunting size of the document but it is also because of the high standard to which the project report is upheld, as stated by Dong (1998). The writing challenge is not only on demonstrating the technical knowledge that is related to the research, but also on using that knowledge to present understandably and coherently the meaning and content of the research results. Apart from that, the skill of writing is one of the determinant factors in getting an employment opportunity once students have graduated (Ahmad et al, 2010). According to Fernandez Polo (2009), since English is now the lingua franca of science and engineering, it is very important to master all the components of English skills.

Academic writing which includes the final year project report writing has grown dramatically over the years. 
(Zhu, 2004). Writing in English for native English speakers may not become a problem. However, for nonnative English speakers, writing in English may lead to major obstacles. Flowerdew (1999) in his study stated that non-native English speakers may face difficulties in writing for academic publication or reports. These obstacles are like the inability to use proper grammar, citations, and to deliver precisely the meaning of a sentence. There are a number of researchers apart from Flowerdew who have done excellent reviews on the difficulties that need to be overcome by non-native English speakers who want to write in English. Li (2002) had successfully described the perceptions of researchers from China in using English for their report. On the other hand, Okamora (2006) has highlighted in his paper the types of strategies used by the Japanese researchers when it comes to writing their findings in English. It was found that one of the difficulties faced by Japanese scientists was lacking of vocabulary which has negatively affect their delivery of accurate results in sentences (Okamora, 2006).

Final year students in UTeM who are required to come out with final year projects are expected to write up the project reports. For this requirement, students are given choice either to write in English or Malay. While resources of information are predominantly in English, many students are yet struggling to write their project papers due to the constraints of being second language learners of English. Wart (2009) in his study found that students felt unprepared by their previous education to read engineering materials in English. Shahrom et al. (2010) has explained that apart from writing skills, understanding what to be written is the primary factors that motivate a writer.

As for this study, the hypothesis is the students have difficulties in writing their final year project report. In other words, the focus of this study is aimed at looking for the motivating and hindering factors for engineering students to write in English for their project report. As writing is concerned, this study will also look at the problems that students constantly have in their writing. The tasks of understanding, selecting and integrating resources to their projects, not to forget the problem of composing the paper which is always influenced by their first language, have always been the complaints from students. Many students do not begin to learn how to approach this task until they are in the process of writing a report or dissertation.

In addition to that, being second language learners of English, students often find it a challenge to write particularly in the engineering field.

UTeM as a public higher institution that focuses on technical field has always inspired to be one of the world's leading innovative and creative technical universities. Therefore, there is an urge for this research to be done so that the students can be taught to have knowledge sharing culture that brings them close to the international professional community. To achieve this, the university certainly owes them in equipping them with the knowledge and skills needed.

\section{Research Methodology}

In this research, quantitative and descriptive designs were employed. The data for this research was obtained by means of questionnaire by which the questions were drafted specifically for UTeM students. The questionnaire comprised of demographic variables and two sub components of English writing skills. These components were self-assessment of English writing and the use of learning strategies. The main objective of this research is to determine the factors that affect the student's language choice in writing their final year engineering report. The results obtained will be used to gauge students ability to write in English for their final year engineering report. Apart from that, the results are useful in determining whether subject relevant to English language enhancement satisfy the students expectation.

\subsection{Sample Data Collection Procedure}

This research involved 201 final year bachelor engineering students from 3 faculties of Universiti Teknikal Malaysia Melaka (UTeM). The faculties are Faculty of Mechanical Engineering (FKM), Faculty of Electrical Engineering (FKE) and Faculty of Electronics and Computer Engineering (FKEKK). The students were given brief explanation on the objective of this research and instruction was given on how to respond to the questionnaire.

\subsection{Questionnaire Designs}

The questionnaire comprises of three parts. The first part is on the demography of the respondents which are faculty, gender, age, race, use of language in report, and Cumulative Grade Point Average (CGPA). The second part of the questionnaire consists of the statements of self- assessment of English writing skills. The last part of the questionnaire comprises of the assessment on the use of learning strategies of the respondents. Mean score is given based on skill 1 to 5 . Skill 1 refers to Never and skill 5 refers to Most Often. 


\subsection{Data Analysis}

The Statistical Package of the Social Science (SPSS version 15.0) was used to analyze and interpret the data obtained from the questionnaire. This data was organized, simplified and presented in the form that is easier to be understood. The results of this study are presented in the form of respondent demography and the descriptive analysis.

\section{Results and discussion}

\subsection{Analysis of Results Based on Respondent Demography}

Demographic data gathered from the respondents are faculty, gender, age, race, choose of language for final year project report, (CGPA) and results of Malaysian University English Test (MUET). The analysis shows that majority of the respondents are students from Faculty of Mechanical Engineering UTeM with a total of 38.3\%, the second highest number of respondents is students from Faculty of Electronics and Computer Engineering with $34.6 \%$ and the rest are students of Faculty of Electrical Engineering.

Apart from that, from the total of 201 respondents, $69.2 \%$ are male students and the rest are female students. On the other hand, $33.3 \%$ of them are at the age of 23 which is the common age for final year engineering students in Malaysia. Table 1 shows the detail of age distribution of respondents that have participated in the research.

From the table 1, the oldest respondent is at the age of 31 years old. In term of race distribution, out of the 201 respondents, $85.1 \%$ are Malay, $10.4 \%$ are Chinese, and $3 \%$ are Indians while $1.5 \%$ is other races. This is typical of Malaysia as a multiracial country. Apart from that, $89.6 \%$ students have chosen to write their final year project reports in English while the rest opted to write in Malay Language.

The other demographic data that has been considered in this research is the students CGPA. Majority of the students have the CGPA between 2.51-3.00. Table 2 shows the details of CGPA distribution of the respondents.

Last but not least, the students' MUET results were also asked in the questionnaire. It is learned that out of the total 201 respondents, $52.7 \%$ have obtained Band 3 in their MUET test. On the other hand, $25.4 \%$ are under Band 2 and 16.4\% belong to Band 4. Band 1 indicates extremely limited user, Band 2 for limited user, Band 3 for modest user, Band 4 for competent user, Band 5 for good user and Band 6 indicates very good user.

\subsection{Self-Assessment of English Writing Skills}

Table 3 depicts the respondent distribution pertaining to the self- assessment of English writing skills. The mean score for this section is 3.84 which is significantly higher than the average value. This shows that the respondents are able to utilize their English language skills without much predicament in writing their final year report. Majority of the respondents are fully aware of the benefits of the information technology which can be used to improve their writing process. However, some respondents may have some difficulties in using appropriate vocabulary and words to explain their research works in sentences. Apart from that, many respondents find it difficult to write the summary of what they have read from English written

sources. The mean score for male respondent for self- assessment part is 3.90 while the female mean score is 3.71 .

\subsection{Use of Learning Strategies}

On the other hand, table 4 shows the respondent distribution based on the use of learning strategies in writing their final year report. The mean score for this section is 3.30. The value is less that the mean score in section 3.1. This means that the use of strategies in learning English may not be well optimized by the respondents. However, the mean score is higher than the average value. This shows that the majority of the students are able to write English report without facing many obstacles. However, going into more details of the results revealed that the respondents require more time to write their report as English is not their mother tongue. Apart from that, many of them are not confident with their level of English. However, from the statements, students are able to identify the problems in their writing and do the enhancement on their skills of writing in English. The mean score for male respondents for use of learning strategies part is 3.28 while the mean score for female respondents is 3.32 .

\section{Conclusion}

This project is done to determine the motivating factors and obstacles faced by the students of Universiti Teknikal Malaysia Melaka. Majority of the students have no major problem in writing their final year project report in English. However, since English is not their mother tongue, more time is required for them to accomplish the writing stage within the given time. Besides that, the students are fully aware that there are technological software available that can help them to improve their skills of writing. The results of this study 
can be potentially used for more detail study in order to improve the level of English among students from various engineering faculties in UTeM. In addition to that, improvement can be made to the relevant English subjects that are offered throughout the four years degree programme.

\section{Acknowledgement}

The authors would like to express sincere gratitude to Universiti Teknikal Malaysia Melaka for sponsoring this research project.

\section{References}

Ahmad Y.M.Y., Wan M.H.W.M.S, Affidah, M.M., Noor, I.A.G. \& Farawaheeda, R. (2010). The English Proficiency of Civil Engineering Students. Asian Social Science, 6(6), 161-170.

Amy, C. \& Dawn, B. (2007). Writing at the graduate level: What tasks do professors actually require? Journal of English for Academic Purposes, 6, 206-221. http://dx.doi.org/10.1016/j.jeap.2007.09.008

Barksdale-Ladd, M.A., Draper, M., King, J., Oropallo, K. \& Radencich, M.C. (2001). Four approaches to preservice teacher's involvement in the writing of case stories: a qualitative research project. Teaching and Teacher Education, 17, 417-431. http://dx.doi.org/10.1016/S0742-051X(01)00004-X

Campbella, G. M., Ellisb, J. B. \& Manistac, F. (2010). Encouraging engineers to read: A book-based final year assessment . Education for chemical engineers, 5, 87-99. http://dx.doi.org/10.1016/j.ece.2010.08.002

Christine P. C. (2010). Taking risks?: A case study of three doctoral students writing qualitative dissertations at an American university in Japan. Journal of Second Language Writing, 19, 1-16. http://dx.doi.org/10.1016/j.jslw.2009.12.002

Diane, P. (2003). Good and original: Plagiarism and patch writing in academic second-language writing. Journal of Second Language Writing, 12, 317-345. http://dx.doi.org/10.1016/j.jslw.2003.08.004

Dong, Y.R. (1998). Non-native Graduate Students' Thesis/Dissertation Writing in Science: Self-reports by Students and Their Advisors from Two U.S. Institutions . English for Specific Purposes, 17(4), 369-390.

Fernandez Polo, F.J. \& Cal Varela, M. (2009). English for research purposes at the University of Santiago de Compostela: a survey. Journal of English for Academic Purposes. 8, 152-164. http://dx.doi.org/10.1016/j.jeap.2009.05.003

Flowerdew, J. (1999). Problems in Writing for Scholarly Publication in English: The Case of Hong Kong. Journal of Second Language Writings, 8(3), 243-264. http://dx.doi.org/10.1016/S1060-3743(99)80116-7

Javier, F., Polo \& F., Varela, M. C. (2009). English for research purposes at the University of Santiago de Compostela: a survey. Journal of English for Academic Purposes, 8, 152-164. http://dx.doi.org/10.1016/j.jeap.2009.05.003

Li,Y. (2002). Writing for international publication: the perceptions of Chinese doctoral researchers. Asian Journal of English Language Teaching, 12, 179-194.

Nancy, D. (2011). Writing for publication for the first time - Try the hunter style. International Journal of Physiotherapy and Rehabilitation, 1(2), 38-45.

Noraini, I. \& Radha, M.K.N. (2011). Writing In Foreign Lands: The Case Of Postgraduate International Students and the Introductory Sections of a Project Paper. Procedia Social and Behavioral Sciences, 18, 626-632. http://dx.doi.org/10.1016/j.sbspro.2011.05.092

Okamura, A. (2006). Two types of strategies used by Japanese scientists, when writing research articles in English. System, 34, 68-79. http://dx.doi.org/10.1016/j.system.2005.03.006

Sara, C. W. (2004). Integrating reading and writing in a competency test for non-native speakers of English. Assessing Writing, 9, 27-55. http://dx.doi.org/10.1016/j.asw.2004.01.002

Tuanhua, L. (2010). Correcting the errors in the writing of university students in the comfortable atmosphere. International Education Studies, 3, 74-78. [Online] Available: http://www.ccsenet.org/ies (June 30, 2011).

Ward, J. (2009). A basic engineering word list for less proficient engineering undergraduates. English for Specific Purposes, 28, 170-182. http://dx.doi.org/10.1016/j.esp.2009.04.001

Xiaoye Y. (2004). The choice made from no choice: English writing instruction in a Chinese University. Journal of Second Language Writing, 13, 97-110. http://dx.doi.org/10.1016/j.jslw.2003.11.001

Zhu, W. (2004). Faculty views on the importance of writing the nature of academic writing, and teaching and 
responding to writing in the disciplines. Journal of Second Language Writing, 13, 29-48. http://dx.doi.org/10.1016/j.jslw.2004.04.004

Table 1. Age distribution of the respondents

\begin{tabular}{|c|c|c|}
\hline Age & $\begin{array}{c}\text { Frequency, } \\
\mathrm{N}\end{array}$ & $\begin{array}{c}\text { Percentage, } \\
\%\end{array}$ \\
\hline 21.00 & 5 & 2.5 \\
\hline 22.00 & 14 & 7.0 \\
\hline 23.00 & 67 & 33.3 \\
\hline 24.00 & 45 & 22.4 \\
\hline 25.00 & 47 & 23.4 \\
\hline 26.00 & 17 & 8.5 \\
\hline 27.00 & 3 & 1.5 \\
\hline 28.00 & 1 & .5 \\
\hline 30.00 & 1 & .5 \\
\hline 31.00 & 1 & .5 \\
\hline Total & 201 & 100.0 \\
\hline
\end{tabular}

Table 2. CGPA distribution of the respondents

\begin{tabular}{|c|c|c|}
\hline $\begin{array}{c}\text { CGPA } \\
\text { Scale }\end{array}$ & $\begin{array}{c}\text { Frequency, } \\
\mathrm{N}\end{array}$ & Percentage, $\%$ \\
\hline $2.00-2.50$ & 3 & 1.5 \\
\hline $2.51-3.00$ & 108 & 53.7 \\
\hline $3.01-3.50$ & 80 & 39.8 \\
\hline $3.51-4.00$ & 10 & 5.0 \\
\hline 25.00 & 47 & 23.4 \\
\hline 26.00 & 17 & 8.5 \\
\hline 27.00 & 3 & 1.5 \\
\hline Total & 201 & 100.0 \\
\hline
\end{tabular}


Table 3. Respondents distribution based on Self-Assessment of English Writing skills

\begin{tabular}{|c|c|c|c|c|c|}
\hline Self- Assessment of English Writing skills & $\begin{array}{l}\overline{0} \\
\grave{0} \\
z\end{array}$ & 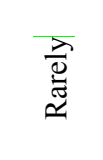 & 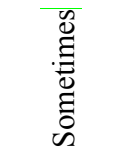 & $\underbrace{\bar{\Xi}}_{0}$ & 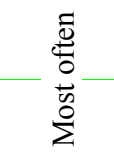 \\
\hline $\begin{array}{l}\text { I can organize my ideas from my native language to English } \\
\text { when I write a paragraph. }\end{array}$ & $\begin{array}{c}0 \\
(0.0 \%)\end{array}$ & $\begin{array}{c}2 \\
(1.0 \%)\end{array}$ & $\begin{array}{c}67 \\
(33.3 \%)\end{array}$ & $\begin{array}{c}107 \\
(53.2 \%)\end{array}$ & $\begin{array}{c}25 \\
(12.4 \%)\end{array}$ \\
\hline $\begin{array}{l}\text { I can write using an academic style and tone as required for my } \\
\text { final year report. }\end{array}$ & $\begin{array}{c}0 \\
(0.0 \%)\end{array}$ & $\begin{array}{c}6 \\
(3.0 \%)\end{array}$ & $\begin{array}{c}70 \\
(34.8 \%)\end{array}$ & $\begin{array}{c}111 \\
(55.2 \%)\end{array}$ & $\begin{array}{c}14 \\
(7.0 \%)\end{array}$ \\
\hline $\begin{array}{l}\text { I can use appropriate vocabulary and word forms to effectively } \\
\text { communicate with the reader. }\end{array}$ & $\begin{array}{c}0 \\
(0.0 \%) \\
\end{array}$ & $\begin{array}{c}11 \\
(5.5 \%) \\
\end{array}$ & $\begin{array}{c}93 \\
(46.3 \%) \\
\end{array}$ & $\begin{array}{c}79 \\
(39.3 \%) \\
\end{array}$ & $\begin{array}{c}18 \\
(9.0 \%) \\
\end{array}$ \\
\hline I can use appropriate spelling, capitalization and punctuation. & $\begin{array}{c}0 \\
(0.0 \%) \\
\end{array}$ & $\begin{array}{c}6 \\
(3.0 \%) \\
\end{array}$ & $\begin{array}{c}76 \\
(37.8 \%) \\
\end{array}$ & $\begin{array}{c}95 \\
(47.3 \%) \\
\end{array}$ & $\begin{array}{c}24 \\
(11.9 \%) \\
\end{array}$ \\
\hline $\begin{array}{l}\text { I can write an accurate summary of information that I have read } \\
\text { in English. }\end{array}$ & $\begin{array}{c}0 \\
(0.0 \%)\end{array}$ & $\begin{array}{c}6 \\
(3.0 \%)\end{array}$ & $\begin{array}{c}91 \\
(45.3 \%)\end{array}$ & $\begin{array}{c}82 \\
(40.8 \%)\end{array}$ & $\begin{array}{c}22 \\
(10.9 \%)\end{array}$ \\
\hline $\begin{array}{l}\text { I can logically support and develop my report with paraphrases, } \\
\text { summaries and quotations. }\end{array}$ & $\begin{array}{c}0 \\
(0.0 \%) \\
\end{array}$ & $\begin{array}{c}5 \\
(2.5 \%) \\
\end{array}$ & $\begin{array}{c}87 \\
(43.3 \%) \\
\end{array}$ & $\begin{array}{c}93 \\
(46.3 \%) \\
\end{array}$ & $\begin{array}{c}16 \\
(8.0 \%) \\
\end{array}$ \\
\hline $\begin{array}{l}\text { I find new technology such as the internet helps me a lot in } \\
\text { writing my report in English (e.g. online dictionary, Google } \\
\text { translator, online journals). }\end{array}$ & $\begin{array}{c}0 \\
(0.0 \%)\end{array}$ & $\begin{array}{c}2 \\
(1.0 \%)\end{array}$ & $\begin{array}{c}35 \\
(17.4 \%)\end{array}$ & $\begin{array}{c}75 \\
(37.3 \%)\end{array}$ & $\begin{array}{c}89 \\
(44.3 \%)\end{array}$ \\
\hline I can find many engineering resources for my project in English. & $\begin{array}{c}0 \\
(0.0 \%) \\
\end{array}$ & $\begin{array}{c}2 \\
(1.0 \%) \\
\end{array}$ & $\begin{array}{c}32 \\
(15.9 \%)\end{array}$ & $\begin{array}{c}97 \\
(48.3 \%)\end{array}$ & $\begin{array}{c}70 \\
(34.8 \%)\end{array}$ \\
\hline $\begin{array}{l}\text { I find that Technical Communication subject helps me a lot in } \\
\text { preparing my final year report. }\end{array}$ & $\begin{array}{c}1 \\
(.5 \%)\end{array}$ & $\begin{array}{c}2 \\
(1.0 \%)\end{array}$ & $\begin{array}{c}64 \\
(31.8 \%)\end{array}$ & $\begin{array}{c}87 \\
(43.3 \%) \\
\end{array}$ & $\begin{array}{c}47 \\
(23.4 \%) \\
\end{array}$ \\
\hline $\begin{array}{l}\text { I think writing my report in English can be important because it } \\
\text { will someday be useful in getting me a good job. }\end{array}$ & $\begin{array}{c}1 \\
(.5 \%) \\
\end{array}$ & $\begin{array}{c}0 \\
(0.0 \%) \\
\end{array}$ & $\begin{array}{c}29 \\
(14.4 \%)\end{array}$ & $\begin{array}{c}80 \\
(39.8 \%)\end{array}$ & $\begin{array}{c}91 \\
(45.3 \%) \\
\end{array}$ \\
\hline
\end{tabular}

Table 4. Respondents distribution based on the use of learning strategies in writing their final year report

\begin{tabular}{|c|c|c|c|c|c|}
\hline Use Of Learning Strategies & $\begin{array}{l}\dot{0} \\
\dot{0} \\
z\end{array}$ & 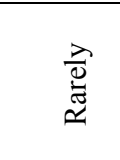 & 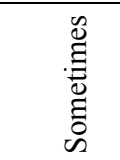 & $\stackrel{巳}{巳}$ & 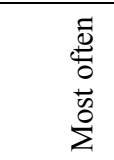 \\
\hline $\begin{array}{l}\text { I need more time to write in English } \\
\text { compared to my native language. }\end{array}$ & $\begin{array}{l}6 \\
(3.0 \%) \\
\end{array}$ & $\begin{array}{l}20 \\
(10.0 \%)\end{array}$ & $\begin{array}{l}73 \\
(36.3 \%) \\
\end{array}$ & $\begin{array}{l}79 \\
(39.3 \%)\end{array}$ & $\begin{array}{l}23 \\
(11.4 \%)\end{array}$ \\
\hline $\begin{array}{l}\text { I am able to discuss my draft with my } \\
\text { project supervisor to get feedback on how I } \\
\text { can improve it. }\end{array}$ & $\begin{array}{l}0 \\
(0.0 \%)\end{array}$ & $\begin{array}{l}3 \\
(1.5 \%)\end{array}$ & $\begin{array}{l}47 \\
(23.4 \%)\end{array}$ & $\begin{array}{l}100 \\
(49.8 \%)\end{array}$ & $\begin{array}{l}51 \\
(25.4 \%)\end{array}$ \\
\hline $\begin{array}{l}\text { I can identify problems in my English } \\
\text { writing and see what should be improved. }\end{array}$ & $\begin{array}{l}0 \\
(0.0 \%)\end{array}$ & $\begin{array}{l}5 \\
(2.5 \%)\end{array}$ & $\begin{array}{l}64 \\
(31.8 \%)\end{array}$ & $\begin{array}{l}110 \\
(54.7 \%)\end{array}$ & $\begin{array}{l}22 \\
(10.9 \%)\end{array}$ \\
\hline $\begin{array}{l}\text { I am not confident with my English } \\
\text { language writing skill. }\end{array}$ & $\begin{array}{l}10 \\
(5.0 \%)\end{array}$ & $\begin{array}{l}40 \\
(19.9 \%)\end{array}$ & $\begin{array}{l}101 \\
(50.2 \%)\end{array}$ & $\begin{array}{l}42 \\
(20.9 \%)\end{array}$ & $\begin{array}{l}8 \\
(4.0 \%)\end{array}$ \\
\hline I practise English with other students. & $\begin{array}{l}6 \\
(3.0 \%)\end{array}$ & $\begin{array}{l}36 \\
(17.9 \%)\end{array}$ & $\begin{array}{l}98 \\
(48.8 \%)\end{array}$ & $\begin{array}{l}51 \\
(25.4 \%)\end{array}$ & $\begin{array}{l}10 \\
(5.0 \%)\end{array}$ \\
\hline $\begin{array}{l}\text { I have problem to organize my thoughts } \\
\text { from my native language to English. }\end{array}$ & $\begin{array}{l}8 \\
8.0 \%)\end{array}$ & $\begin{array}{l}46 \\
(22.9 \%)\end{array}$ & $\begin{array}{l}97 \\
(48.3 \%)\end{array}$ & $\begin{array}{l}44 \\
(21.9 \%)\end{array}$ & $\begin{array}{l}6 \\
(3.0 \%)\end{array}$ \\
\hline $\begin{array}{l}\text { I have problem to produce grammatically } \\
\text { and structurally correct sentences in English. }\end{array}$ & $\begin{array}{l}5 \\
(2.5 \%)\end{array}$ & $\begin{array}{l}42 \\
(20.9 \%)\end{array}$ & $\begin{array}{l}96 \\
(47.8 \%)\end{array}$ & $\begin{array}{l}49 \\
(24.4 \%)\end{array}$ & $\begin{array}{l}9 \\
(4.5 \%)\end{array}$ \\
\hline $\begin{array}{l}\text { Preparing my final year project report in } \\
\text { English will take longer time for me. }\end{array}$ & $\begin{array}{l}20 \\
(10.0 \%)\end{array}$ & $\begin{array}{l}35 \\
(17.4 \%)\end{array}$ & $\begin{array}{l}77 \\
(38.3 \%)\end{array}$ & $\begin{array}{l}53 \\
(26.4 \%)\end{array}$ & $\begin{array}{l}16 \\
(8.0 \%)\end{array}$ \\
\hline
\end{tabular}

